\title{
Social Return of R\&D investments in Manufacturing Sector: Some Insights from an Exploratory Case Study Jorge Cunha ${ }^{(1)}$, Paula Ferreira ${ }^{(2)}$, Madalena Araújo ${ }^{(3)}$, Enrique Ares-Gomes ${ }^{(4)}$
}

(1) Department of Productions and Systems, University of Minho, Portugal, jscunha@dps.uminho.pt

(2) Department of Productions and Systems, University of Minho, Portugal, paulaf@dps.uminho.pt (3) Department of Productions and Systems, University of Minho, Portugal, mmaraujo@dps.uminho.pt

(4) Technical Superior School of Industrial Engineers, University of Vigo, Spain, enrares@uvigo.es

\begin{abstract}
This paper aims at contributing to the literature on how to measure the social impact of Research and Development (R\&D) investment projects. For that purpose, an exploratory case study was undertaken to assess the importance that companies give to the social return of R\&D investments and to identify the criteria and indicators more relevant for this evaluation process. The research undertaken is based on interviews conducted as part of a case study methodology involving a maritime-sector private company and the Technological Center of the Sea in Vigo. The results indicate that the criteria chosen as being the most important for the evaluation of social return of R\&D were the number of jobs created at the company, the environmental impact and the working conditions. Also, in the case of Support Programs for R\&D applications funding the research results indicate that the evaluation process presently followed does not properly address the socio-economic factors.
\end{abstract}

Keywords: R\&D investment, Social return, Project evaluation, Maritime Sector, Case study

\begin{abstract}
RESUMEN
Este artículo pretende ser una contribución a la literatura existente sobre la forma de medir el impacto social de los proyectos de inversión en Investigación y Desarrollo (I\&D). Con este fin se llevó a cabo un estudio de exploración para poder evaluar la importancia que las empresas dan al retorno social que se obtiene de las inversiones en proyectos de investigación y cuáles son los criterios e indicadores más relevantes en el proceso de evaluación. La investigación llevada a cabo se basa en entrevistas realizadas como parte de la metodología aplicada al estudio de una empresa privada del sector marino y al Centro Tecnológico del Mar en Vigo. Los resultados indican que los criterios elegidos para la evaluación del retorno social de los proyectos I\&D, los más importantes fueron el número de puestos de trabajo creados en la empresa, el impacto ambiental y las condiciones de trabajo. Además se concluye que el proceso de evaluación llevado a cabo sobre los Programas de Apoyo para solicitudes de financiación en I\&D, en la actualidad no aborda adecuadamente los factores socio-económicos.
\end{abstract}

Palabras clave: Inversión en I\&D, Retorno social, Evaluación de proyecto, Sector marítimo, Caso de estudio

\section{Introduction}

Over the years companies have generally based the assessment of their projects on financial criteria in order to achieve the best economic performance. This is why the academic community has proposed several methods that can help to improve capital investment decisions of companies. These investment evaluation criteria are indicators that help to determine the financial convenience to undertake an investment project, according to their economic performance or expected profitability, that is, if the net cash flows generated during their lifetime outweigh the initial investment.

During recent decades, the globalization of financial markets, the intensifying competition among companies, financial institutions and organizations, as well as the rapid economic and social development and technological changes have led to growing uncertainty and instability in the financial situation and business environments [1]. Simultaneously, in order to achieve higher profits and to maximize the value of the company, managers seek a differentiation with the rest of their competitors, which implies, in some cases, to invest in $R \& D$ projects. 
Investment in $\mathrm{R} \& \mathrm{D}$ is an essential element for increasing competitiveness, especially in technology-based companies [2]. Ref. [2] stressed the importance of not only adopting a financial perspective but also include a qualitative perspective with an appropriate model. In other words, it is necessary to find a suitable methodology which takes into account a range of different criteria that are to be considered when selecting the projects that should be developed [3].

In fact, [4] argue that, from a private company point of view, evaluating R\&D projects is a complicated task. But, in spite of these difficulties, these evaluations are fundamental due to the competitive environment surrounding R\&D investing companies.

Although several criteria (or perspectives/measures) can be included in the analysis in this context, this paper draws attention on a particular, but important, issue - how to measure the social return of investment in $\mathrm{R} \& \mathrm{D}$ projects. For that purpose, the main findings of an exploratory case study on maritime sector are described. While this issue is also important in the case of programs of public agencies to stimulate $R \& D$ investment, the focus of attention was on $R \& D$ activities undertaken by private corporations.

The remainder of this paper is organized as follows. Section 2 presents a brief overview of the literature on R\&D investment and social return. Section 3 describes the research methodology followed in the study. Section 4 shows the main findings obtained. Finally, section 5 presents the conclusions and perspective of future work.

\section{Literature overview}

\subsection{R\&D investment and social return}

As emphasized by [3], the net present value (NPV) of a project in R\&D is virtually impossible to calculate. Companies are looking for new technologies, yet to be developed, where it is impossible to extrapolate probabilities from past experiences. Companies must make all their assessments while minimizing any information leaks to their competitors. Moreover, [4] highlight the need for compatibility between the R\&D project and the company's mission, underlying also that companies are supposed to foresee the obtained benefits. Also [5] justifies the importance of R\&D performance measurement: motivating researchers and engineers and improving their performance, controlling the progress of R\&D activities regarding objectives of resources consumption, time and technical requirements, evaluating the cost-reducing contribution of $\mathrm{R} \& \mathrm{D}$ activities to the company, reducing the uncertainty and promoting organizational learning.

Therefore, it seems that there is a need for companies to include in their decision-making process other than financial criteria (e.g. strategy, flexibility, quality, social return). In fact, these non-financial aspects are particularly important in the new industrial environment in which firms today operate, where new technological developments tend to occur more rapidly than the evolution of project-evaluation techniques [6].

One aspect that emerges in the literature is the social impact of R\&D investment. In fact, the different contributions from the study of technology are concerned with the need to incorporate social criteria in the field of scientific research and engineering. These contributions allow us to establish a new concept of technological change based on the co-evolution of technology and society [7].

The concept of social impact can be broadly defined as a combination of multiple environmental, socioeconomic and scientific factors which are often left out of traditional mechanisms for evaluating R\&D [8]. Over time social responsibility is gaining importance and companies are trying to find a proper balance between economic profitability and social responsibility. The consideration of social impact begins to be seen as a potential source of profit, as it increases the degree of consumer confidence and reduces the likelihood of conflicts among the different groups affected [9].

From a standpoint that gives priority to social criteria rather than to economic effects, it is necessary to carry out a sector analysis and the identification of measures and actions which may enable to determine whether social return on investment in R\&D exists. According to [10], such factors can be considered to be either positive or negative effects of public investment in R\&D.

An interesting study that tackles this theme is presented by [11]. The author presents 11 programs which support R\&D activities from the Government of Canada and describes a method of analysis to see the economic and social impact. A large number of methods were proposed to analyze those programs such as: Internal Rate of Return (IRR), the Cost-Benefit Analysis (CBA), Econometric studies, and 
Microeconomic Analysis. The author proposes also the inclusion of a set of non-financial indicators, turning the analysis more complete and focusing it towards the concept of social return.

Another recent work of research conducted by [12], presents an analysis of different programs of public financing for Portugal in the R\&D area. In order to be able to accomplish a comparison among these programs, a set of qualitative and quantitative indicators that can characterize the attained objectives was used. From the quantitative results of the interviews with experts the order of importance of the considered criteria was derived: formation, conditions of employment, ambient/ energy, social return against financial return, job and finally the return on investment.

These two papers [11] and [12] were centered on evaluating the social impact of R\&D from the perspective of public programs that stimulate and fund those investments. The interest in this study was on the private perspective. In order to do so, it was necessary to identify (or define) what criteria/indicators should be included in the analysis.

\subsection{Selection of indicators}

To undertake the empirical study, a selection of indicators directly related to the measurement of the social return of R\&D programs was made. This selection of indicators was based on the works of [10], [12], [13] and also on the Spanish Observatory of Invention and Knowledge (ICONO) web page.

The selected categories of indicators were: Employment; Working conditions; Learning and growth; Social return vs. Financial return; Environmental Effects; and Investment rates. For each one of these categories, a set of indicators was proposed:

Employment: Creation of employment: increase of the total number of places of work in the company; Creation of employment: increase of the total number of places out of the company; Increase of the number of places of work for socially disadvantaged communities; women; immigrant.

Working conditions: Quality of employment-ergonomics; Wage level; Level of training: increase of knowledge and capacities; Security; Degree of satisfaction of the employees; Good working environment; Maintenance and consolidation of existent places.

Learning and growth: Improvement of the competences of the R\&D personnel; Boost the culture of R\&D; Diffusion of knowledge (scholarships, patents); Creation of spin-off (number of companies created from the knowledge obtained by the project and that are kept independent; Transfer of knowledge; Know-How; Platform for growth.

Social Return: Improvement of the social satisfaction; Resolution of problems like unemployment, delinquency, immigration; Contribution for the regional development; Contribution for regional, national or European politics; Social effect in the operation of market: transfer of companies, outsourcing, boost the spirit of the technological innovation.

Financial Return: Increase of company's productivity; Increase of market share; Reduction of costs; Financial stability of the company; Economic effect in the operation of market: creation of new companies, increase of the productivity; Sales of new products.

Environmental effects: Reduction of pollution; Protection of the environment; Reduction of energy consumption; Use of renewable energy sources.

Investment rate: New infrastructures of R\&D; Investment in human capital (e.g. education, human skills, academic performance).

The importance that companies give to each one of these indicators was analyzed in the empirical study undertaken.

\section{Research Methodology}

In the study undertaken, the research methodology adopted was exploratory in nature and based on the case study approach. An exploratory approach usually produces conclusions and assumptions that could be tested or used in future investigations [14]. For [15], a case study is, generally, a "description of a management situation". It is an approach that allows analyzing in depth several aspects of a real situation: the case study. 
Ref. [16] argues that the case study does not involve the use of a specific test and can be based on both the quantitative and qualitative evidence. The test (or findings) may result from fieldwork, archival documents, comments, or a combination of the three. The case study does not also require a specific methodology for collecting data.

The empirical study presented in this research paper is centered at the maritime sector, where opinions of a private company operating in the sector (Ronautica, SA) and of the Technological Center of the Sea (CETMAR) about the social impact and social return of R\&D are described. The case study methodology was utilized previously in works of [5] and [12], but focusing primarily on how the Support Programs evaluate $R \& D$ projects.

In order to carry out this research project a two-part interview was chosen. The first addresses questions whose aim is to deepen on the subject and which are of great interest to the interviewer, who can add more questions during the interview if appropriate. In the second part, a standard questionnaire was used which enables the comparison of answers provided by different respondents and to quantify the results obtained. The option for this kind of interviews was based on the fact that it allows a more flexible way in terms of data collection and with a highest response rate, as the interviewee agrees more and more to be controlled by the interviewer, despite the fact that it is obviously a laborious methodology which demands much time. Figure 1 summarizes the approach followed during the research.

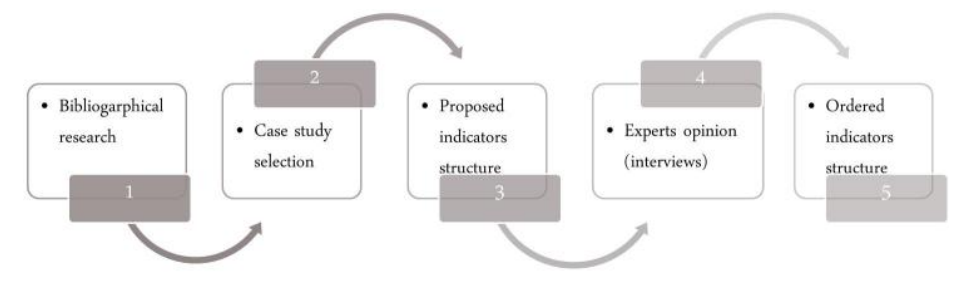

Figure 1. Research framework.

Both organizations included in the research were involved in R\&D projects financed with public funds. The main objectives of the empirical study were: (1) to determine which of the proposed indicators are assumed to be more important for project evaluation and how this indicators may be associated to the concept of social return; (2) to assess the importance of this social return concept at the moment of project elaboration.

\section{Findings}

\subsection{Qualitative Analysis}

The qualitative analysis of these interviews allowed to collect information about R\&D projects in general and about the evaluation conducted at the company or at the technological center. The main findings in this regard were:

1) Difficulties in getting financing: Both interviewees emphasize that there are always difficulties at the moment of getting financing and on the eligibility of expenses. This may even lead to the impossibility of carry out with the project.

2) Social objectives: The company does not deal with social objectives during the project evaluation process. In fact, for $95 \%$ of the company's projects, most of the objectives are of financial nature. The environmental benefits that the company gets from the creation of new and more ecological products and environmental friendly processes are frequently collateral consequences of the project and not pre-defined objectives. The Technological Center, however, gives more attention to social objectives of the project during the project follow-up and evaluation. Nonetheless, neither the analyzed company nor the technological center resorts to a predefined set of indicators to evaluate the impact of R\&D projects.

\subsection{Quantitative Analysis}

This quantitative analysis aimed to establish a ranking of the indicators that could be used to evaluate the social return of a publicly funded project. This ranking was based on the weights assigned by the company and by the technological center. 
From the private company point of view, the main criteria, and respective indicators, that could be used to evaluate social return are, in order of importance, the following:

$1^{\circ}$ Employment, and the most notable indicator was "creation of employment: increase of the total number of places of job in the company".

$2^{\circ}$ Environmental impact and, in particular, the most important indicator was "utilization of renewable energy sources".

$3^{\text {o }}$ Working conditions, where the most important indicators were "level of training: increase of knowledge and capacities (polyvalence); security; and degree of satisfaction of the employees".

From the technological center point of view, the major criteria, and respective indicators, that could be used to evaluate social return are, in order of importance, the following:

$1^{\circ}$ Employment, and the most notable indicator was "creation of employment: increase of the total number of places of work in the company".

$2^{\circ}$ Learning and growth, measured especially by these indicators: "knowledge production"; Working conditions; Security; Degree of satisfaction of the employees".

$3^{\circ}$ Environmental impact, considering the indicators: "Reduction of the pollution"; "Reduction of the energy consumption"; "Use of renewable energy sources" (all considered equally important).

$4^{\circ}$ Social return vs. the financial return. For the social return the most notable indicators are: "Resolution of problems like unemployment, relocation, delinquency, immigration"; "Contribution to the regional development"; "Contribution to regional, national, or European politics", all valued with the same weight. For the financial return the most important indicators are: "Increase of the productivity for the company"; "Economic effect in the operation of market (like the creation of new companies)", also valued with the same weight.

\subsection{Analysis of the criteria used in the process of evaluating applications for funding}

In this section, the evaluation criteria included in the public calls of Support programs in which the company R\&D projects and technological centre projects were included will be analyzed.

For the company, the project data were taken from the website: www.ronautica.com [17]. In the following paragraphs, for each project a brief description of the criteria/indicators considered in the Support programs is presented.

- Project 1, under "The Galician Research, Development and Technological Innovation Plan" (PGIDIT) 2006-2010. Code: IN841C-2006/314

The objective of the call was to promote business innovation in the Autonomous Community of Galicia. Included criteria were: environmental implications, significant pollution reduction, reduction of energy consumption, importance and capacity of the Project to solve problems in the sector (maximum 14 points over 100) and creation of new jobs and significant presence of women on the team (maximum 8 points over 100). In total, the assigned social value was $22 \%$. The technical criterion was worth $50 \%$.

- Project 2, under PGIDIT 2006-2010. Code PGIDIT06CCP007.

This included public calls from sectoral programs of Natural Resources, Innovation Technologies and Services. The only criterion related to the social impact is the significant presence of women researchers in the research team with 2 points assigned out of 100 . So, $2 \%$ of the evaluated related to the social value. The scientific and technical criterion was the most important one weighting $70 \%$ of the overall evaluation.

- Project 3, under PGIDIT 1999-2001 and 2002-2005. Code PGIDT01MAR05Y.

This call related to the Plan Marino Gallego for Research Program and Technological Development. No evaluation criteria related to the social impact was found.

- Project 4, under PGIDIT 1999-2001. Code PGIDT00INN33Y

This was included in a public call from the Support Program to Innovation of Plan Gallego for Research and Technological Development. Once more, this call does not include any social criteria for the evaluation. 
For the case of the technological centre, the projects address mainly Control and Management of coastal and maritime resources. Projects' objectives can be found at its website: www.cetmar.org [18]. In the following paragraphs, for each project, a brief description of the criteria/indicators considered in the Support programs is presented.

- Project 1, funding: European Union. Multinational Cooperation Program Atlantic Area.

Social indicators displayed on the call are:

Extent to which the project responds to challenges common to all the territory of the Atlantic Area. Weight $7 / 100$.

Positioning of the project in an ascending scale of four levels of intensity of cooperation: exchange of experiences, knowledge transfer, sharing of resources and problems solving, development of a transnational strategy. Weight $7 / 100$.

Demonstration of the sustainability strategy of the project to allow to proceed with the project activity beyond the funding period, including the possible leverage effect through the involvement of new actors, sectors or regions. Weight $6 / 100$.

Relevance and realism of the communication plan and its contribution to the transferability of the results of the project including the transfer of knowledge and best practices to expand the Atlantic Area (for new audiences, sectors or regions). Weight 6/100.

Relevance, realism, and tangible value of performance indicators and results and their relation to the objectives of the project. Relevance of monitoring indicators presented. Weight 6/100.

Extent to which the project demonstrates, through information, such as the issues and challenges of the project correspond to the objectives and problems common to Member States / regions of the Atlantic Area. Weight 5/100.

Extent to which the project promotes and facilitates the transfer of knowledge and know-how and exchange of experiences within the partnership. Weight $4 / 100$.

In sum, these indicators represented a weight of 50\% compared to the total. Each project is graded between 0 and 5 for each of the twenty criteria that may be found in the Candidate Handbook from the website (http://atlanticarea.inescporto.pt/).

- Project 2, Financing: General Directorate of R\&D. Ministry of Economy and Industry. Plano INCITE Eranet AMPERA (FP VI Program). Xunta de Galicia.

The most valuable criterion in this case is the scientific and technical merit with a maximum of 70 points out of 100. Those criteria that may be included in a social category are: number of $\mathrm{PhD}$, incorporation of new $\mathrm{PhD}$, balanced participation of women researchers in the project, with a maximum of 4 points on 100. Use of Galician language with 2.5 points out of 100 . This represents a total of $6.5 \%$ in social valuation.

- Project 3, Funding: Ministry of the Sea .Xunta de Galicia.

Social criteria pre-defined in the order of October 20, 2008 are the criteria for test methods to improve gear selectivity of fishing and environmental impact with 8 points on 100 and follow good environmental practices with a weight of 2 points on 100 . This implies that social value is $10 \%$ of the total. The most valued is the scientific-technical quality and innovation with a weight of $40 \%$ of the total.

\section{Discussion of findings}

The objective of the interviews conducted (in a maritime sector company and in the technology center of the sea) was to identify and to rank the criteria and indicators more used when assessing R\&D investments, with an emphasis on those criteria focusing/measuring the social return of R\&D.

The major finding of these interviews was that, for the case of the private company, when carrying out projects social objectives are not taken into account. On the other hand, for the case of the technology center of the sea, when formulating and evaluating their R\&D projects social objectives are already considered. Nevertheless, both interviewees seem to be not fully aware of the concept of social return and how it should be measured. In fact, the criteria the interviewee selected as most important for evaluating the social return were Employment (with a particular emphasis on the Number of jobs created in the company), Environmental impact and Working conditions. 
After analyzing the calls to the R\&D support programs, it could be concluded that a match seems to exist between the criteria that the firm and technological center consider to be related and/or assume to be important to measure the social return, and the criteria included in the R\&D support program calls. Taking into account the possibility that a relationship may exist between the social criteria that are required in the calls and the concept of social return for companies and agencies, the following hypothesis may be proposed:

"The social criteria appearing in the calls can influence business objectives and agencies applying to the support program. Companies frequently prepare the project by finding the lines of the call that best suits the companies' needs and characteristics. For example, if the call requires environmental objectives the project will end up having environmental improvements. That is, there is a possibility that setting a greater number of social criteria for project evaluation under a specific R\&D support program, will lead to increase awareness for social return on the company goals and to the need to accomplish predefined minimum social goals."

To test this hypothesis more interviews and an in-depth analysis of public R\&D support programs calls seems to be fundamental. It must be underlined that the discussed result represent the point of view of the interviewees and may not be universally accepted. In fact, the conclusions drawn from a case study cannot be generalized [19]. But, as underlined by [20], the case study methodology can generate theory from the practice.

\section{Conclusions}

This paper is a part of an ongoing research project focusing on the social impact of R\&D investments and support programs from the perspectives of the public and private sectors This paper has focused on the private perspective, and the objective was to establish a set of variables or indicators that can be used to assess the social return of R\&D investment projects. Therefore, a set of criteria and indicators were identified in order to measure the social return more than the economic or scientific impact.

The research methodology used was an exploratory case study based on interviews to the manager of a maritime sector company and the manager of the technology centre of the sea, in order to assess the possible social return generated by $R \& D$ investments and which criteria and indicators were more relevant.

From the interviews results, it seems that the company does not take into account social objectives when carrying out projects. The technology centre, however, takes already into account some social objectives when elaborating and evaluating their projects. However, both interviewees have a limited idea of what is the social return and what criteria may be used to measure it, indicating a clear lack of awareness to that concept. The criteria the interviewee selected as most important for evaluating the social returns are: employment (particularly, the number of jobs created in the company); environmental; and working conditions.

Although this work is only an exploratory study with a small number of interviews, it is possible to present some general conclusions and recommendations for future work. Figure 2 summarizes the main conclusions of the research.

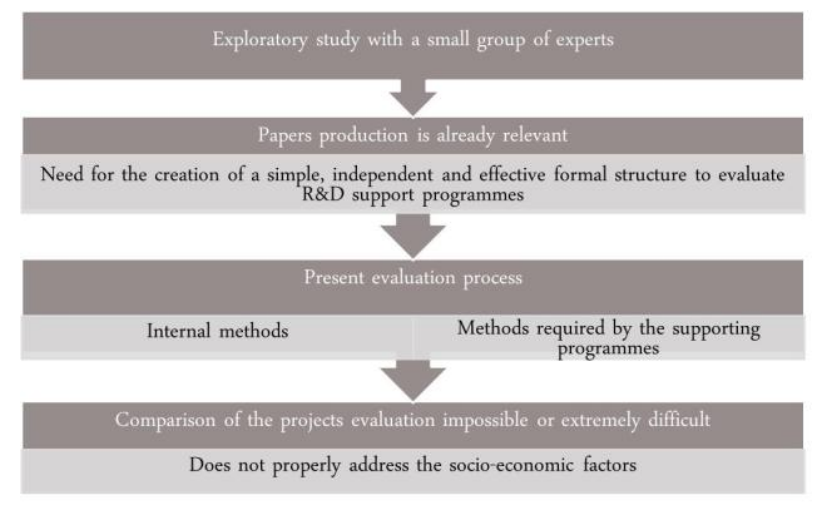

Figure 2. Research summary and main conclusions.

From the bibliographic research done, it is possible to conclude that the papers production in the area of socio-economic return of support programmes to R\&D projects is already relevant. Presently, the 
evaluation process of R\&D projects is usually based on internal methods or on methods required by the supporting programs. This makes the comparison of the projects evaluation impossible or extremely difficult. Also, the type of evaluation presently done does not properly address the socio-economic factors.

The next steps to be followed include: more data research, standardization of the indicators, and application of the proposed ordered structure of indicators to a set of funded projects in order to evaluate the support program performance and to create some case studies in this area.

\section{References}

[1] C. Zopounidis and M. Doumpos, Multi-criteria Decision Aid in Financial Decision Making: Methodologies and Literature Review, J. Multi-Crit. Decis. Anal. 11 (2002).

[2] W.R. Bitman and N.Sharif, A Conceptual Framework for Ranking R\&D Projects, IEEE T Eng Maange 55 (2008) 2.

[3] M. Henig and H. Katz, $R \& D$ Project Selection: A Decision Process Approach, J. Multi-Crit. Decis. Anal. 5 (1996).

[4] R.P. Mohanty, R. Agarwal, A. K. Choudhury and M. K .Tiwari, A fuzzy ANP-based approach to R\&D project selection: a case study, Int J Prod Res 43 (2005) 24.

[5] V. Chiesa, F. Frattini, V. Lazzarotti, and V. Manzini, Performance measurement in $R \& D$ : exploring the interplay between measurement objectives, dimensions of performance and contextual factors, R\&D Manage 39 (2009) 5.

[6] P. Brownell and K. A. Merchant, The Budgetary and Performance Influences of Product Standardization and Manufacturing Process Automation, J Account Res (1990).

[7] A. Rip and R. Kemp, Technological Change.In: Rayner, S. and Malone, L. Human Choice and Climate Change. Volume II. Resources and Technology, Batelle Press, Washington D.C (USA), 1998.

[8] A. Moñux, C. Gomez, and M. Velasco, Evaluación del impacto social de proyectos de Investigación y Desarrollo tecnológico $(I+D)$ :Una aplicación en el sector de las comunicaciones industriales, 2006.

[9] A.B.Carroll, and A. Buchholtz, Business and Society. Ethics and Stakeholder Management, SouthWestern Publishing, 2009.

[10] E. Ares Gómez, A.P. Dominguez, E. Quintela, F.J. Fernández-López, and M. Doiro-Sancho, Análisis del "Retorno Social" de la financiación pública de la I+D+i"; Observatório Industrial del Sector del Metal; elaborado pela Área de Ingenieria de los Processos de Fabricación da Universidade de Vigo, 2008.

[11] B. Cozzarin, Performance measures for the socio-economic impact of government spending on $R \& D$, Scientometrics (2006).

[12] M. Carvalho, Análise do retorno económico-social do investimento público em Investigação e Desenvolvimento (I\&D): aplicação na área da Energia / Ambiente, Dissertação de Mestrado em Engenharia Industrial, Universidade do Minho, 2009.

[13] M.S. Álvarez Gómez, Análise e avaliação de programas de Investigação e Desenvolvimento (I\&D), Dissertação de Mestrado Integrado em Engenharia e Gestão Industrial, Universidade do Minho, Novembro 2009.

[14] B. Ryan, R. Scapens, and M. Theobald, Research method and methodology in finance and accounting, London: Thomson (UK), 2002.

[15] T.V. Bonoma, Case research in marketing: opportunities, problems, and a process, J Marketing Res 22 (1985).

[16] R.K. Yin, The case study crisis: some answers, Admin Sci Quart 26 (1981).

[17] www.ronautica.com

[18] www.cetmar.org

[19] G.G. Gable, Integrating case study and survey research methods: an example in information Systems, Eur J Inform Syst 3 (1994) 2.

[20] I. Benbasat, D.K. Goldstein, and M. Melissa, The case research in studies of information systems, MIS Quart (1987). 